\title{
LONG-TERM TRENDS IN BIRD POPULATIONS ON AN ELECTRIC TRANSMISSION RIGHT-OF-WAY
}

\author{
by Richard H. Yahner', Russell J. Hutnik', and Stephen A. Liscinsky²
}

\begin{abstract}
We conducted a 2-year study of bird populations on the Green Lane Research and Demonstration Project, which is located along a 500-kV transmission line right-of-way (ROW) of the Philadelphia Electric Company, in the Piedmont Province, Montgomery County, Pennsylvania, U.S., in spring and summer 2001 and 2002. The objectives of our study were to (1) determine the diversity and relative abundance of bird populations in spring versus summer on the ROW, (2) compare bird use among five representative treatment units of the ROW, and (3) compare use of wire zones versus border zones on the ROW. In addition, bird populations in this study were compared to those observed on the ROW in 1987 and 1988. Forty-four species (including one hybrid) were observed on the ROW during 2001 and 2002. In 1987 and 1988 combined, 42 species were noted on the ROW; thus, despite continued mechanical and herbicidal maintenance of the right-of-way, the bird community has changed very little over the past 15 years. More species were observed on the ROW in spring than in summer. Common bird species on the ROW in one or both seasons were those adapted to early successional or edge habitats. Total abundance of all species combined, however, was higher in summer than in spring, in part because of the presence of many family groups (parents and fledgling young). Most species were found in the mowing plus herbicide unit and the fewest were noted in the foliage-spray unit. Considerably more birds were observed in border zones than in wire zones of the ROW. Thus, border zones are very important habitat for birds along a ROW, with its combination of shrub-forb-
\end{abstract} grass cover type.

Key Words. Birds; herbicides; populations; rights-of-way; tree control.

The Green Lane Research and Demonstration Project has been ongoing since 1987, making it one of the longest continuous studies examining the effects of mechanical and herbicidal maintenance on flora and fauna along an electric transmission right-of-way (ROW) (Yahner et al. 2002a). This longterm project is very important to utility companies, foresters, wildlife biologists, the public, and others by providing a comprehensive ecological understanding of the response of biota to rights-of-way management.

The Green Lane Research and Demonstration Area is located along a 500-kV transmission line right-of-way of the Philadelphia Electric Company GPU Energy in the Piedmont Province, Montgomery County, Pennsylvania, U.S. Since the inception of this project, a maintenance technique, termed the wire zone/border zone method (Bramble et al. 1992), has been used for all treatment units on the ROW (Figure 1). This technique is designed to produce a forb-low shrubgrass cover type in wire zones that is resistant to undesirable (target) trees while maintaining a shrub cover type in border zones, thereby creating a diverse wildlife habitat on the ROW (Yahner et al. 2002b).

Long-term research studies, such as those at Green Lane and State Game Lands 33, are invaluable for understanding the effects of land uses on fauna (e.g., bird populations) (Saunders et al. 1991; Yahner et al. 2002b). Long-term studies of bird populations, in particular, are timely because certain species (e.g., early successional species) have experienced declines over recent decades, partially because of forest maturation in the U.S. northeast (Yahner 2000a, 2000b; Hunter et al. 2001). Electric transmission line rights-of-way are linear corridors that create early successional habitat in otherwise contiguous forested tracts; hence, studies of bird populations in and along rights-of-way are relevant because 
birds can be indicators of the effects of vegetative management on the local ecosystem (Bramble et al. 1992).

The objectives of this study were to (1) determine the diversity and relative abundance of breeding bird populations in spring versus summer on the ROW, (2) compare bird use among five representative treatment units of the ROW, and (3) compare use of wire zones versus border zones on the ROW. In addition, bird populations in this study were compared to those observed on the ROW in 1987 and 1988 (Bramble et al. 1992).

\section{METHODS}

\section{Vegetation on the ROW}

White ash (Fraxinus americana), sassafras (Sassafras albidum), black cherry (Prunus serotina), and eastern redcedar (Juniperus virginiana) were common trees in border zones, whereas white ash and sassafras were abundant trees in wire zones (Yahner et al. 2002a). Common shrubs on the ROW were blackberry (Rubus allegheniensis) and Japanese honeysuckle (Lonicera japonica); the dominant forb was goldenrod (Solidago spp.).

\section{Treatments on the ROW}

We selected five treatment units for study: mowing $(0.58$ ha), foliage spray (0.50 ha), mowing plus herbicide ( 0.79 ha), stem-foliage spray (0.60 ha) (Figure 2), and handcutting $(0.27 \mathrm{ha})$. The total acreage sampled on the ROW was 2.74 ha, with approximately $50 \%$ each in wire zones and border zones. These were the same treatment units used in previous sampling of bird populations in 1987 and 1988 (Bramble et al. 1992).

Maintenance treatments were applied in July 1999 (details of previous treatments can be found in Yahner et al. 2002a). Briefly, all undesirable trees were cut in wire and border zones of the handcutting unit and in border zones of other units. Wire zones in each unit (excluding handcutting) were mowed and/or treated with herbicides. The mowing unit was shrub-forb cover type in both wire and border zones. The stemfoliage spray unit was forb-grass-shrub cover type in the wire zone and shrubforb cover type in the border zone. The mowing plus herbicide unit was grassforb-shrub cover type in the wire zone and shrub-forb cover type in the border zone. The foliage-spray mowing plus herbicide unit was forb-grass-shrub cover type in the wire zone and shrub-forb cover type in the border zone. Lastly, the handcutting unit was characterized by shrub-tree-forb cover type in both wire and border zones.

\section{Bird Surveys on the ROW}

Bird surveys were conducted for 6 days each in spring (late May to early June) and summer (late July to early August) The spring corresponds to the breeding season, and the summer is the period when young are fledged from the nest and are typically associated in family groups with their parents. Approximately the same schedule was followed in both years. A minimum of 2 years of data is important because of year-to-year differences that may occur in population studies resulting from weather or other biological phenomenon.

Surveys were conducted from sunrise to about 10:00 A.M. (1000 hours). All birds seen or heard were noted to species; if possible, sex and age of each bird were also recorded. The location of each bird (i.e., treatment unit used and whether it was in the wire or the border zone) was determined. The average total number of birds of all species combined per day and the average number of individual birds per species per day were calculated on a per-hectare basis for each treatment ( $\mathrm{n}=5$ treatments) and for each zone (wire versus border) in each season.

\section{RESULTS AND DISCUSSION Diversity and Relative Abundance in Spring Versus Summer}

Thirty-nine and 30 bird species were observed in spring and summer 2001 and 2002, respectively, on the Green Lane Research and Demonstration Area (Table $1^{*}$ ). In both seasons, the three most common species were field sparrow (scientific names are given in Table 1), common yellowthroat,
*All tables are located at the end of this article.

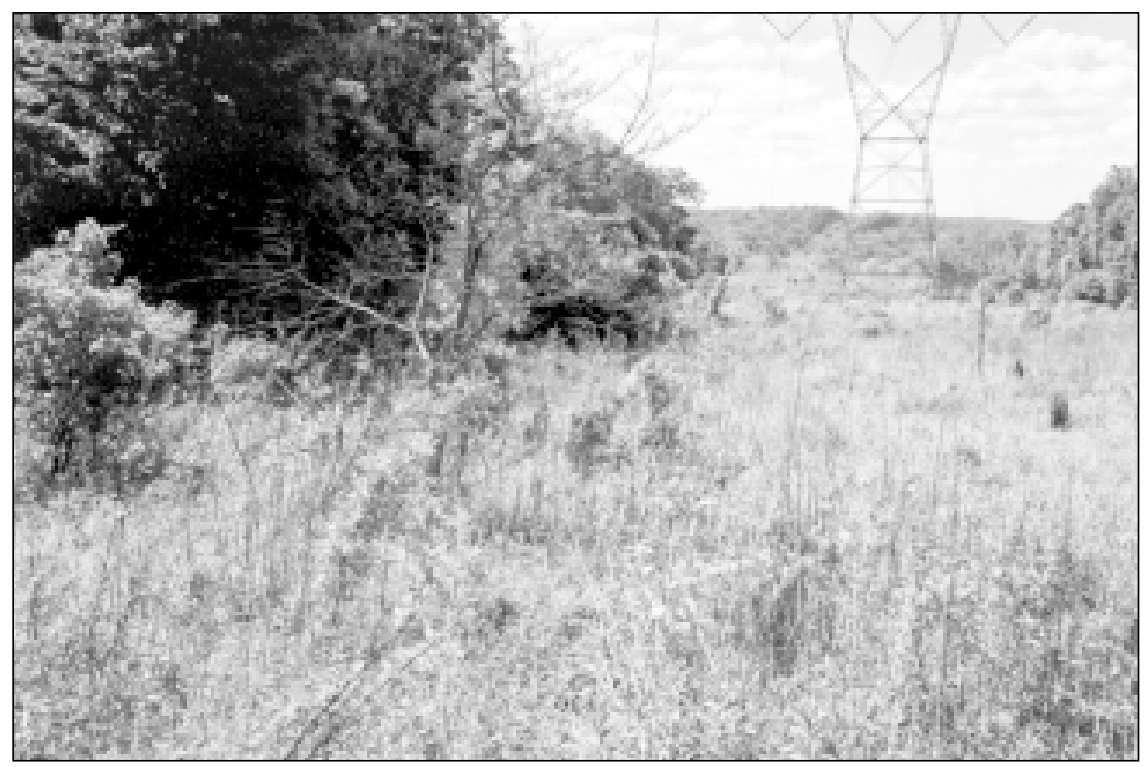

Figure 2. A stem-foliage spray unit on the Green Lane Research and Demonstration Area. The border zone is on the left, and the wire zone is on the right (photo by $R$. Yahner, May 2002). 
and indigo bunting. In spring, prairie warbler, northern cardinal, American goldfinch, gray catbird, and eastern towhee were also abundant. In summer, additional common species included gray catbird, house wren, eastern towhee, northern cardinal, and American goldfinch. Each of these species is adapted to early successional habitats or edge habitats (Fergus 2000), which is characteristic of habitat created by the wire zone/border zone method of vegetative management. Similarly, early successional bird species (e.g., field sparrow, common yellowthroat) were common on the State Game Lands 33 right-of-way in Centre County, Pennsylvania (Yahner et al. 2002b). Early successional habitats are critical to populations of these bird species (Yahner 2000a, 2000b; Hunter et al. 2001), particularly because habitat in Pennsylvania and in the northeastern United States is beginning to revert from abandoned farmland to mature forest (Litvaitis 1993; Yahner 2000a; Hunter et al. 2001).

Bird populations in 2001 and 2002 were quite similar to bird observed in 1987 and 1988, except for subtle differences. For example, 44 bird species (counting the "Brewster's" warbler as a separate "species") were observed in the 20012002 era compared to 42 species in the 1987-1988 era (Bramble et al. 1992). Two common species on the ROW in spring during both eras, blue-winged warbler (and the hybrid, "Brewster's" warbler) and prairie warbler, fledged young and disbanded family groups before the summer counts. These warblers produce one brood each year and then migrate south for winter relatively early in the summer (e.g., Fergus 2000). However, the "Brewster's" warbler [hybrid between blue-winged and golden-winged warbler (Vermivora chrysoptera)] was not seen on the ROW in the 1987-1988 era, but the golden-winged warbler was uncommon.

Infrequently occurring species noted on the ROW in the 1987-1988 era [e.g., mockingbird (Mimus polyglottus)], were seen near the ROW in the 2001-2002 era; conversely, wild turkey were seen on the ROW in 2001 and 2002 but only in the vicinity of the ROW in 1987 and 1988 (Table 1) (Bramble et al. 1992). Brown-headed cowbirds, which are brood parasites, remained low in numbers in both 1987-1988 and 2001-2002 eras (Bramble et al. 1992); that is, the presence of the ROW did not increase cowbird abundance in the area (see Yahner 1995). One notable change, however, was the presence of fish crows on the ROW (Table 1). This species has steadily increased its numbers and geographic range throughout Pennsylvania and the U.S. northeast in recent years (Fergus 2002).

Total abundance of all species combined was relatively similar between spring (1,572 birds/100 ha/day) and summer (1,630 birds/100 ha/day) (Table 1). A factor contributing to a somewhat higher total abundance in summer than in spring was the presence of many family groups on the ROW in summer (Table 2). Family groups of 15 species were observed on the ROW, totaling 252 family groups/100 ha/day. The most frequently encountered family groups were those of common yellowthroat, gray catbird, field sparrow, house wren, indigo bunting, eastern towhee, and northern cardinal. In addition, family groups of woodland species (e.g., black-capped chickadee and tufted titmouse) were observed on the ROW. Similar results were found on the State Game Lands 33 Research and Demonstration Area in Centre County, Pennsylvania (Yahner et al. 2002b). Other recent studies have shown that early successional habitats are important to family groups or fledgling forest birds as sources of food and cover (e.g., Pagen et al. 2000). Presumably, many family groups of these 15 species were present on the ROW in summer because of abundant arthropods (insects, etc.) as food for young (e.g., Yahner et al. 2002b). In several cases during summer, adult birds were noted with food in their beaks, which probably was intended for young fledgling birds in the immediate vicinity (R. Yahner, personal observation). Thus, the Green Lane Research and Demonstration Area, which is managed via the wire zone/border zone method, provided food and cover for numerous family groups of early successional, edge, and woodland bird species.

Several bird species were not seen on the ROW but were noted within the immediate vicinity $(<200 \mathrm{~m})$ or flying over the ROW in 2001 or 2002. These were great blue heron (Ardea herodias), turkey vulture (Cathartes aura), Cooper's hawk (Accipiter cooperii), black-billed cuckoo (Coccyzus erythropthalmus), hairy woodpecker (Picoides villosus), pileated woodpecker (Dryocopus pileatus), tree swallow (Tachycineta bicolor), mockingbird, white-crowned sparrow [Zonotrichia leucophyrs (migrant)], and rose-breasted grosbeak (Pheucticus ludovicianus).

\section{Diversity and Relative Abundance Among Treatments}

The number of species per unit varied from 23 in the foliage-spray unit to 33 in the mowing plus herbicide unit (Table 3). The number of species per unit may be partially a function of unit area, with mowing plus herbicide being the largest unit. Total abundance of all species combined was highest in the handcutting unit (2,571 birds/100 ha/day) versus other units (1,246 to 1,764 birds/100 ha/day). Also, high abundance in the handcutting unit was attributed in part to the use of the transmission tower in the unit by fish crows (Table 4) and to the patchy nature of the handcutting unit. This unit was characterized by shrubs and open herbaceous areas, unlike the more homogeneous, shrubby handcutting units found on the State Game Lands 33 Research and Demonstration Area (Yahner et al. 2002b). Interesting, the handcutting unit was the least suitable unit to birds in a previous study (Bramble et al. 1992).

\section{Diversity and Relative Abundance in Wire Versus Border Zones}

Nearly four-fifths (79\%) of the bird observations on the Green Lane ROW in 2001 and 2002 were in border zones, despite border zones being approximately equal in area to 
that of wire zones (Table 5). This finding attests to the importance of this zone to bird populations and to the relevance of the wire zone/border zone method as a sound wildlife management practice along rights-of-way. Border zones tended to be more often used by birds in the two mowed units (mowing and mowing plus herbicides) than in the other units (88\% versus $66 \%$ to $75 \%$, respectively).

Nonmowed units were characterized by some shrubs in the wire zone, which were used as perch sites by birds (Figure 3). Hence, a combination of wire zones and border zones, regardless of treatment type, provides a variety of habitats for numerous bird species adapted to various vegetative cover types along a right-of-way.

Of the total number of bird observations $(\mathrm{n}=1,059)$ on the Green Lane ROW in both years, 53 (5\%) were birds perched on transmission wires or on transmission-

line towers (Table 4). Thus, 11 bird species used wire zones to some extent because of the presence of artificial substrates (e.g., either wires or towers, rather than vegetation created by the right-of-way management). Only the mourning dove used the wires as perch sites, whereas the other ten species used the towers as perch sites.

In summary, based on this 2-year study, the bird community on the Green Lane Research and Demonstration Area is quite diverse on all treatment units. In addition, despite continued mechanical and herbicidal maintenance of the right-of-way, the bird community has changed very little over the past 15 years. Bird species on the ROW are adapted to early successional or edge habitats created by the wire zone/ border zone method; species in the summer also include those that breed in woodlands but use the ROW as foraging sites. This study also confirms the importance of the border zone as habitat to birds in both spring and summer. The presence of many family groups of birds supports the fact that food resources are common on the ROW. We strongly recommend the use of the wire-zone border-zone method for rights-of-way management.

\section{LITERATURE CITED}

Bramble, W.C., R.H. Yahner, and W.R. Byrnes. 1992.

Breeding-bird population changes following right-of-way maintenance treatments. J. Arboric. 18:23-32.

Fergus, C. 2000. Wildlife of Pennsylvania and the Northeast. Stackpole Books, Mechanicsburg, PA. 438 pp.

Hunter, W.C., D.A. Buehler, R.A. Canterbury, J.L. Confer, and P.B. Hamel. 2001. Conservation of disturbance-dependent birds in eastern North America. Wildl. Soc. Bull. 29:440-455.

Litvaitis, J.A. 1993. Response of early successional vertebrates to historic changes in land use. Conserv. Biol. 7:866-881

Pagen, R.W., F.R. Thompson, III, and D.E. Burhans. 2000. Breeding and post-breeding habitat use by forest migrant songbirds. Condor 102:738-747.

Saunders, D.A., R.J. Hobbs, and C.R. Margules. 1991.

Biological consequences of ecosystem fragmentation: A review. Conserv. Biol. 5:18-32.

Yahner, R.H. 1995. Forest-dividing corridors and Neotropical migrant birds. Conserv. Biol. 9:476-477.

- 2000a. Eastern Deciduous Forest: Ecology and Wildlife Conservation. University of Minnesota Press, MN. 295 pp.

2000b. Long-term effects of even-aged management on bird communities in central Pennsylvania. Wildl. Soc. Bull. 28:1102-1110.

Yahner, R.H., R.J. Hutnik, and S.A. Liscinsky. 2002a. Green Lane Research and Demonstration Project. Annual Report to Cooperators. 49 pp.

. 2002b. Bird populations associated with an electric transmission right-of-way. J. Arboric. 28:123-130. 
Acknowledgments. Cooperators were Asplundh Tree Expert Tree Company, Dow AgroSciences, and PECO An Exelon Company. We also thank Environmental Consultants, Inc., for their cooperation with this study.

${ }^{1 *}$ School of Forest Resources

The Pennsylvania State University

University Park, PA 16802, U.S.

2623 S. Fraser St.

State College, PA 16801, U.S.

*Corresponding author: Richard Yahner.

Résumé. Nous avons mené une étude sur 2 ans concernant les populations d'oiseaux dans le cadre du Projet de recherche et de démonstration sur les emprises vertes localisé le long d'une ligne électrique de $500 \mathrm{kV}$ de la Compagnie d'électricité de Philadelphie en Pennsylvanie, et ce au cours des printemps (fin mai, début juin) et étés (fin juillet, début août) 2001 et 2002. Les objectifs de notre étude étaient de: 1) déterminer la diversité et l'abondance relative des populations d'oiseaux au printemps versus en été au sein de l'emprise; 2) comparer l'usage par les oiseaux de cinq unités représentatives de traitements dans l'emprise; 3) comparer l'usage des zones sous les fils électriques versus celles en périphérie (bordure) des fils. De plus, les populations d'oiseaux dans cette étude ont été comparées à celles observées dans cette même emprise en 1987-88. Quarantequatre espèces (incluant une hybride) ont été observées dans l'emprise durant 2001-02. En 1987 et 1988 combinées, 42 espèces ont été notées dans l'emprise; donc, en dépit des interventions mécaniques et avec herbicides sur une base continue, la communauté ailée a peu changé au cours des 15 dernières années. Plus d'espèces étaient observées dans l'emprise au printemps qu'en été. Les espèces communes d'oiseaux dans l'emprise au cours de une ou des deux saisons étaient celles qui étaient les mieux adaptées à une succession rapide d'habitat ou encore à des habitats périphériques, comme le pinson des champs (Spizella pusilla), la fauvette masquée (Geothlypis trichas), le bruant indigo (Passerina cyanea), le moqueur chat (Dumetella carolinensis) et le la fauvette des prés (Dendroica discolor). Labondance totale de toutes les espèces combinées était néanmoins supérieure en été qu'au printemps, en partie en raison de la présence de plusieurs groupes familiaux (parents et jeunes oisillons). Plus d'espèces étaient retrouvées dans l'unité fauchée et traitée avec herbicide, tandis que la quantité la plus faible était dans l'unité traitée par vaporisation foliaire. Considérablement plus d'oiseaux étaient observés dans les zones en bordure des fils que celles situées sous les fils électriques. De ce fait, les zones en bordure sont un habitat très important pour les oiseaux le long d'une emprise de ligne électrique, et ce avec son couvert combiné d'arbustes, d'herbacées et de graminées. En résumé, la méthode d'entretien des zones en bordure et sous les fils crée un habitat convenable pour une variété d'espèces d'oiseaux au sein de toutes les unités de traitements. La grande diversité d'espèces d'oiseaux parmi les deux saisons, combinée avec la présence de plusieurs groupes familiaux en été, particulièrement dans les zones en bordure, confirment le fait que les ressources en habitat et en nourriture sont facilement disponibles au sein des emprises de lignes.

Zusammenfassung. Wir leiteten im Frühling (Mai-Juni) und Sommer (Juli-August) 2001-02 eine 2-jährige Studie über die Vogelpopulation im Green Lane Forschungs- und Demonstrationsprojekt, welches entlang einer $500 \mathrm{kV}$ Überlandleitung (ROW) der Philadelphia Elektrikgesellschaft in Piedmont Province,Montgom. County, Pennsyl., liegt. Die Ziele unserer Studie waren 1. die Diversität und das relative Vorkommen von Vogelpopulationen im Frühling versus Sommer in der ROW zu bestimmen, 2. die Nutzung durch Vögel von 5 repräsentativen Behandlungsflächen in der ROW und 3. die Nutzung von Randzonen versus Bereichen unterhalb der Kabel zu vergleichen. Zusätzlich wurden die Vogelpopulationen mit denen aus den Untersuchungen von 1987-88 verglichen. 44 Arten (inkl. 1 Hybride) wurden 2001-02 beobachtet. In Verbindung mit der Studie von 1987-88 wurden 42 Arten notiert, trotz kontinuierlicher mechanischer und pestizidgebrauchender Behandlungen hat die Vogelgemeinde sich in den letzten 15 Jahren nur gering verändert. Im Frühling wurden mehr Arten als im Sommer beobachtet. Die gewöhnlichen Vögel in der ROW während der beiden Phasen waren diejenigen, die an frühes Brüten adaptiert waren, z.B (Spizella pusilla), (Geothlypis trichas), (Passerina cyanea), (Dumetella carolinensis), und (Dendroica discolor). Das totale Vorkommen aller Arten zusammengefasst, war im Sommer dennoch größer als im Frühling wegen der großen Familiengruppen mit Jungvögeln. Die meisten Arten wurden in den Einheiten mit der Behandlung Mähen + Herbizid und am wenigsten in Einheiten mit Blattherbizidauftrag gefunden. Verständlicherweise wurden mehr Arten in den Randbezirken notiert. Die Randbezirke mit ihrer Busch-Strauch-GrasBedeckung sind bedeutende Vogelhabitate. Zusammenfassend ist die Kabelzone/Randzone in der ROW-Erhaltungspflege ein wichtiges Habitat für eine Vielzahl von Vogelarten. Die hohe Diversität der Vogelarten zu beiden Jahreszeiten zusammengefasst, in Verbindung mit der Anwesenheit der großen Familiengruppen im Sommer, besonders in Randbezirken, unterstützt die Tatsache, das Habitat und Futterquelle in der ROW gegeben sind. 
Resumen. Se realizó un estudio de dos años de poblaciones de aves en el proyecto demostrativo de Green Lane, el cual está localizado a lo largo del derecho de vía de la línea de transmisión (ROW) de la Compañía Eléctrica de Philadelphia, en la Provincia Piedemonte, del Condado Montgomery, Pennsylvania, en primavera (Mayo-Junio) y verano (Julio-Agosto) de 2001-2002. Los objetivos del estudio fueron: (1)determinar la diversidad y abundancia relativa de poblaciones de pájaros en primavera versus verano en el ROW, (2) comparar el uso de las aves entre cinco tratamientos representativos en ROW, y (3) comparar el uso de zonas con alambrado versus zonas de frontera en ROW. Además, las poblaciones de aves en este estudio fueron comparadas a las observadas en la ROW en 1987 88. Cuarenta y cuatro especies (incluyendo un híbrido) fueron observadas en el ROW durante 2001-02. En 1987 y 1988 combinados, otra vez 42 especies fueron observadas en el ROW. Por lo tanto, a pesar del continuo manejo mecánico y con herbicidas del derecho de vía, la comunidad de aves ha cambiado muy poco en los pasados 15 años.

Fueron observadas más especies de aves en primavera que en verano. Las especies más comunes fueron el gorrión (Spizella pusilla), el pecho amarillo común (Geothlypis trichas), el gorrión índigo (Passerina cyanea), el "catbird" (Dumetella carolinensis), y el pájaro cantor (Dendroica discolor). La abundancia total combinada de todas las especies, sin embargo, fue más alta en verano que en primavera, en parte por la presencia de muchas grupos de familias (pajarillos jóvenes). Considerablemente más pájaros fueron observados en las zonas de frontera que en las zonas alambradas del ROW. Por consiguiente, las zonas de frontera son un hábitat muy importante para las aves en una ROW con una combinación de coberturas de arbustos y pastos. En resumen, el manejo de las zonas de frontera proporciona áreas deseables para las aves en todas las unidades de tratamiento. La alta diversidad de aves en las dos estaciones, combinada con la presencia de muchos grupos de familias en el verano, particularmente en la zona de frontera, apoya el hecho de que el hábitat y los recursos de alimentos son comunes en el ROW. 
Table 1. Number of birds per individual species/100 ha/day, number of birds of all species combined/100 ha/day, and total number of species observed on the Green Lane Research and Demonstration Area in spring versus summer 2001 and 2002 based on both years combined and all treatment units combined. Abundance of an individual species is underlined in a given season if exceeding $125 \mathrm{birds} / 100 \mathrm{ha} / \mathrm{day}$.

\begin{tabular}{|c|c|c|}
\hline \multirow[b]{2}{*}{ Bird species } & \multicolumn{2}{|c|}{ Season } \\
\hline & Spring & Summer \\
\hline Field sparrow (Spizella pusilla) & $\underline{270}$ & $\underline{204}$ \\
\hline Common yellowthroat (Geothlypis trichas) & $\underline{149}$ & $\overline{234}$ \\
\hline Indigo bunting (Passerina cyanea) & $\underline{182}$ & $\underline{149}$ \\
\hline Gray catbird (Dumetella carolinensis) & 82 & $\underline{164}$ \\
\hline Northern cardinal (Cardinalis cardinalis) & 106 & 115 \\
\hline Eastern towhee (Pipilo erythrophthalmus) & 82 & 121 \\
\hline American goldfinch (Carduelis tristis) & 88 & 77 \\
\hline Prairie warbler (Dendroica discolor) & $\underline{131}$ & 0 \\
\hline House wren (Troglodytes aedon) & 0 & 115 \\
\hline Blue jay (Cyanocitta cristata) & 27 & 52 \\
\hline Tufted titmouse (Baeolophus bicolor) & 49 & 24 \\
\hline Yellow-breasted chat (Icteria virens) & 58 & 6 \\
\hline Carolina wren (Thryothorus ludovicianus) & 21 & 43 \\
\hline Eastern phoebe (Sayornis phoebe) & 15 & 49 \\
\hline Blue-winged warbler (Vermivora pinus) & 61 & 0 \\
\hline Black-capped chickadee (Poecile atricapillus) & 15 & 43 \\
\hline Fish crow (Corvus ossifragus) & 30 & 21 \\
\hline Song sparrow (Melospiza melodia) & 21 & 30 \\
\hline Mourning dove (Zenaida macroura) & 3 & 36 \\
\hline Downy woodpecker (Picoides pubescens) & 3 & 30 \\
\hline Eastern kingbird (Tyrannus tyrannus) & 24 & 6 \\
\hline Brown-headed cowbird (Molothrus ater) & 32 & 0 \\
\hline Great crested flycatcher (Myiarchus crinitus) & 12 & 15 \\
\hline American robin (Turdus migratorius) & 3 & 24 \\
\hline Northern flicker (Colaptes auratus) & 6 & 18 \\
\hline Baltimore oriole (Icterus galbula) & 0 & 18 \\
\hline Eastern bluebird (Sialia sialus) & 15 & 0 \\
\hline Brewster's warbler (Vermivora pinus $\times$ chrysoptera) & 15 & 0 \\
\hline Ruby-throated hummingbird (Archilochus columbris) & 6 & 6 \\
\hline Red-bellied woodpecker (Melanerpes erythrocephalus) & 0 & 12 \\
\hline American crow (Corvus brachyrhynchos) & 12 & 0 \\
\hline Blue-gray gnatcatcher (Polioptila caerulea) & 9 & 3 \\
\hline Scarlet tanager (Piranga olivacea) & 12 & 0 \\
\hline Red-tailed hawk (Buteo jamaicensis) & 3 & 6 \\
\hline Cedar waxwing (Bombycilla cedrorum) & 6 & 0 \\
\hline Red-eyed vireo (Vireo olivaceus) & 3 & 3 \\
\hline Black-and-white warbler (Mniotilta varia) & 6 & 0 \\
\hline Wild turkey (Meleagris gallopavo) & 3 & 0 \\
\hline Eastern wood-pewee (Contopus virens) & 0 & 3 \\
\hline Carolina chickadee (Poecile carolinensis) & 3 & 0 \\
\hline White-breasted nuthatch (Sitta carolinensis) & 0 & 3 \\
\hline Wood thrush (Hylocichla mustelina) & 3 & 0 \\
\hline White-eyed vireo (Vireo griseus) & 3 & 0 \\
\hline Ovenbird (Seiurus aurocapillus) & 3 & 0 \\
\hline All species combined & 1,572 & 1,630 \\
\hline Total number of species & 39 & 30 \\
\hline
\end{tabular}

Table 2. Number of family groups per individual species/100 ha/day and number of family groups of all species combined/100 ha/day observed on the Green Lane Research and Demonstration Area in summer 2001 and 2002 based on both years and all treatment units combined.

\begin{tabular}{lc}
\hline Bird species & No. family groups \\
\hline Common yellowthroat & 57.2 \\
Gray catbird & 36.4 \\
Field sparrow & 36.4 \\
House wren & 24.3 \\
Indigo bunting & 18.4 \\
Eastern towhee & 18.4 \\
Northern cardinal & 18.4 \\
Blue jay & 12.1 \\
Black-capped chickadee & 9.1 \\
Tufted titmouse & 6.1 \\
Eastern phoebe & 6.1 \\
Song sparrow & 6.1 \\
Fish crow & 3.0 \\
Carolina wren & 3.0 \\
American robin & 3.0 \\
All species combined & $\mathbf{2 5 2 . 0}$ \\
\hline
\end{tabular}


Table 3. Number of birds per individual species/100 ha/day, number of bird species of all species combined/100 ha/day, and total number of species observed per treatment unit on the Green Lane Research and Demonstration Area in spring and summer, 2001 and 2002 combined. Treatment units: $M=$ mowing, $F=$ foliage spray, $\mathrm{MH}=$ mowing plus herbicide, $\mathrm{SF}=$ stem-foliage spray, and $\mathrm{HC}=$ handcutting. Abundance of an individual species in a given treatment unit is underlined if exceeding $125 \mathrm{birds} / 100 \mathrm{ha} / \mathrm{day}$.

\begin{tabular}{|c|c|c|c|c|c|}
\hline \multirow[b]{2}{*}{ Bird species } & \multicolumn{5}{|c|}{ Treatment unit } \\
\hline & $\mathrm{M}$ & $\mathrm{F}$ & MH & SF & $\mathrm{HC}$ \\
\hline Field sparrow & $\underline{259}$ & $\underline{274}$ & $\underline{163}$ & 276 & $\underline{250}$ \\
\hline Common yellowthroat & 144 & 199 & 100 & 193 & 327 \\
\hline Indigo bunting & $\underline{138}$ & $\underline{224}$ & $\underline{142}$ & $\overline{111}$ & $\underline{312}$ \\
\hline Gray catbird & 230 & 116 & 68 & 77 & 156 \\
\hline Northern cardinal & $\overline{86}$ & 75 & $\underline{126}$ & 50 & $\underline{316}$ \\
\hline Eastern towhee & 101 & 100 & 79 & 90 & 172 \\
\hline American goldfinch & 50 & 91 & 26 & $\underline{152}$ & $\underline{140}$ \\
\hline Prairie warbler & 50 & 116 & 38 & 77 & 62 \\
\hline House wren & 14 & 83 & 108 & 40 & 47 \\
\hline Blue jay & 65 & 25 & 53 & 7 & 47 \\
\hline Tufted titmouse & 43 & 0 & 26 & 41 & 78 \\
\hline Yellow-breasted chat & 0 & 50 & 0 & 35 & 156 \\
\hline Carolina wren & 22 & 8 & 38 & 35 & $\overline{16}$ \\
\hline Eastern phoebe & 29 & 25 & 42 & 35 & 31 \\
\hline Blue-winged warbler & 43 & 25 & 21 & 35 & 31 \\
\hline Black-capped chickadee & 14 & 0 & 42 & 41 & 47 \\
\hline Fish crow & 50 & 8 & 16 & 0 & 94 \\
\hline Song sparrow & 86 & 42 & 0 & 0 & 0 \\
\hline Mourning dove & 22 & 17 & 32 & 7 & 16 \\
\hline Downy woodpecker & 7 & 17 & 21 & 14 & 32 \\
\hline Eastern kingbird & 0 & 0 & 10 & 35 & 79 \\
\hline Brown-headed cowbird & 29 & 0 & 10 & 0 & 63 \\
\hline Great crested flycatcher & 7 & 33 & 5 & 21 & 22 \\
\hline American robin & 7 & 0 & 5 & 11 & 79 \\
\hline Northern flicker & 14 & 8 & 0 & 14 & 47 \\
\hline Baltimore oriole & 7 & 8 & 10 & 7 & 16 \\
\hline Eastern bluebird & 7 & 8 & 10 & 7 & 0 \\
\hline "Brewster's" warbler & 7 & 0 & 0 & 28 & 0 \\
\hline Ruby-throated hummingbird & 7 & 0 & 0 & 14 & 16 \\
\hline Red-bellied woodpecker & 0 & 0 & 5 & 7 & 32 \\
\hline American crow & 22 & 0 & 5 & 0 & 0 \\
\hline Blue-gray gnatcatcher & 7 & 0 & 0 & 14 & 16 \\
\hline Scarlet tanager & 0 & 0 & 16 & 0 & 16 \\
\hline Red-tailed hawk & 0 & 0 & 5 & 7 & 0 \\
\hline Cedar waxwing & 0 & 0 & 0 & 14 & 0 \\
\hline Red-eyed vireo & 0 & 8 & 0 & 0 & 16 \\
\hline Black-and-white warbler & 0 & 0 & 0 & 14 & 0 \\
\hline Wild turkey & 0 & 0 & 5 & 0 & 0 \\
\hline Eastern wood-pewee & 0 & 0 & 5 & 0 & 0 \\
\hline Carolina chickadee & 0 & 0 & 5 & 0 & 0 \\
\hline White-breasted nuthatch & 0 & 0 & 5 & 0 & 0 \\
\hline Wood thrush & 7 & 0 & 0 & 0 & 0 \\
\hline White-eyed vireo & 0 & 0 & 5 & 0 & 0 \\
\hline Ovenbird & 0 & 0 & 0 & 7 & 0 \\
\hline All species combined & 1,674 & 1,764 & 1,246 & 1,528 & 2,571 \\
\hline Total number of species & 30 & 23 & 33 & 32 & 30 \\
\hline
\end{tabular}


Table 4. Number of bird observations on transmission-line towers or transmission-line wires on the Green Lane Research and Demonstration Area in 2001 and 2002.

\begin{tabular}{lcc}
\hline Species & Observations on towers & Observations on wires \\
\hline Mourning dove & 0 & 13 \\
Fish crow & 16 & 0 \\
Brown-headed cowbird & 10 & 0 \\
American crow & 3 & 0 \\
Indigo bunting & 3 & 0 \\
Red-tailed hawk & 2 & 0 \\
Eastern kingbird & 2 & 0 \\
Northern flicker & 1 & 0 \\
Eastern phoebe & 1 & 0 \\
Common yellowthroat & 1 & 0 \\
Field sparrow & 1 & 0 \\
Total & 40 & 13 \\
\hline
\end{tabular}

Table 5. Use of wire zones versus border zones by all bird species combined in each of five treatment units on the Green Lane Research and Demonstration Area during springs and summers of 2001 and 2002 combined. Use is based on the percentage of the total number of observations (actual number of observations in parentheses) in a given unit. Treatment units: $\mathrm{M}=$ mowing, $\mathrm{F}$ = foliage spray, $\mathrm{MH}=$ mowing plus herbicide, $\mathrm{SF}=$ stem-foliage spray, and $\mathrm{HC}=$ handcutting. The amount of area in the border zone of each treatment unit is approximately equal to that of the wire zone.

\begin{tabular}{lllllll}
\hline & \multicolumn{7}{c}{ Treatment unit } \\
\cline { 2 - 7 } Zone & $\mathrm{M}$ & $\mathrm{F}$ & $\mathrm{MH}$ & $\mathrm{SF}$ & HC & Total \\
\hline Wire & $12 \%(28)$ & $34 \%(67)$ & $12 \%(27)$ & $25 \%(57)$ & $27 \%(47)$ & $21 \%(226)$ \\
Border & $88 \%(202)$ & $66 \%(130)$ & $88 \%(200)$ & $75 \%(173)$ & $73 \%(57)$ & $79 \%(833)$ \\
\hline
\end{tabular}

